\title{
Characteristics of Innovations in Companies: Comparison of Croatia and Slovenia
}

\author{
Barbara Bradač Hojnik \\ University of Maribor, Maribor, Slovenia
}

\begin{abstract}
Intense competition in past decades, stemming from the opening of national markets and global expansion of production, has forced companies to use all their best resources and core skills to exploit business opportunities. Companies compete in a fast-changing environment, where the key question is how to succeed in such an environment. The only viable answer is to act in such a way to achieve and sustain a competitive advantage through continuous innovation. Companies' performance at different levels of innovation also reflects their innovation performance at the national level. This paper's driving research question examines the innovation performance of companies and, based on the results, defines the main challenges of selected countries to improve companies' innovation abilities and performance. Several methodologies to measure innovation abilities and performance of companies exist; this paper is based on two of them. The first one is the European Innovation Scoreboard, which assesses the innovation performance of selected countries using the Community innovation Survey database. The second is based on SME Performance Review Indicators, which measure the performance of European SMEs in different areas, including innovativeness. These two sources represent the database for the empirical comparison of Slovenia and Croatia. The results indicate that several differences exist between the compared countries and that both face many challenges in developing innovation capabilities of companies and improve policies and mechanisms supporting innovativeness to improve companies' innovation performance.
\end{abstract}

Keywords: innovation challenges, companies, innovation performance, Croatia, Slovenia

\section{Introduction}

The main aim of the European Union established 10 years ago was to become the most developed and competitive region in the world, however, this goal still has not been reached. Reaching this goal requires achieving and sustaining the competitive advantages of companies and, subsequently, of countries. However, in this context, competitive advantage is constantly created and destroyed in a continuous process of Schumpeter's creative destruction. Accordingly, innovation is a condition for sustaining competitive advantages. Therefore, companies must continuously innovate. The traditional idea that innovation is the result of research and interaction between companies and other actors has been replaced by the social network theory of innovation (European Commission, 2004, p. 5). In this sense, knowledge plays a crucial role in fostering innovation.

Barbara Bradač Hojnik, Ph.D., Assistant Professor, Department of Entrepreneurship and Business Economics, Faculty of Economics and Business, University of Maribor.

Correspondence concerning this article should be addressed to Barbara Bradač Hojnik, Faculty of Economics and Business, UM, Razlagova 14, 2000 Maribor, Slovenia. E-mail: barbara.bradac@uni-mb.si. 
However, the level of innovation in European countries is still not high enough. The current research examined the state of innovation in companies by investigating several areas that could provide a more holistic picture of innovation in analysed countries - namely, enablers of innovation activities, types of innovation activities, cooperation and support for performing innovation activities, and results of innovation activities. This paper compares two countries that were historically part of the common state Yugoslavia: Croatia as an EU candidate and Slovenia, who joined the EU in 2004. According to the European Innovation Scoreboard (European Commission, 2010), Slovenia ranks among those countries that are "innovation followers" whereas Croatia is among the "catching-up countries".

\section{Characteristics of Innovation in Companies}

\section{The Need for Innovation}

Intense competition in past decades, open markets, and global production expansion have forced companies to use all their best resources and key skills to exploit business opportunities. In such circumstances, it is necessary to focus scarce resources on core competencies that help foster innovation (Andandre \& Furtado, 2006). Companies can build appropriate competencies and complementary assets by making appropriate choices early and selecting one of several innovation strategies (Freeman \& Soete, 1997): offensive, defensive, imitative, dependent, traditional, or opportunistic.

According to different surveys and research results, major differences in innovation levels exist among European countries. One survey, the European Innovation Scoreboard, which measures innovation performance among European (and other) countries, divides countries into four groups (European Commission, 2010):

- Innovation leaders, whose innovation performance ranks well above average (Denmark, Finland, Germany, Sweden, Switzerland, and the United Kingdom);

- Innovation followers, whose innovation performance is close to average (Austria, Belgium, Cyprus, Estonia, France, Iceland, Ireland, the Netherlands, and Slovenia);

- Moderate innovators, whose innovation performance is below average (the Czech Republic, Greece, Hungary, Italy, Lithuania, Malta, Norway, Poland, Portugal, Slovakia, and Spain);

- Catching-up countries, whose innovation performance is well below average (Bulgaria, Croatia, Latvia, Romania, Serbia, and Turkey).

According to these findings, a lack of innovation exists in most European countries. Although all national economies have implemented several instruments and measures to foster innovation in the business sector, a huge challenge for them remains in applying these effectively and improving performance of all actors involved in national innovation systems.

\section{Sources of Innovation}

A company or its environment must have access to assets and competencies that allow for the production of new ideas and the development of new products or processes. In general, five major sources of innovation exist for a company (Afuah, 2003, p. 69): (1) internal value chain activities; (2) external value-added chain of suppliers, customers, and complementary innovators; (3) universities, government, and private laboratories; (4) competitors and related industries; and (5) other nations or regions. Companies in today's environment cannot rely only on internal sources, they have to acquire knowledge for innovation from their environments as well (Cassiman \& Veugelers, 2006; Rigby \& Zook, 2002).

From external sources, companies typically acquire knowledge through licensing, outsourcing research 
and development, and hiring researchers (Arora \& Gambardella, 1990; Granstrand et al., 1992). Access to external knowledge increases the effectiveness of internal research and development. In general, companies tend to use a combination of internal and external knowledge, although the latter is used as complementary activity (Cassiman \& Veugelers, 2006). Chesbrough (2003) similarly argues that, although the outsourcing of research and development for a given company is very important, monitoring and enforcing the internal research and development to maintain and develop absorption capacity should also be provided as this enables a company to use the acquired results of research and development, known also as innovation capacity. Innovation capacity at the company leaves the ability to implement significant improvements and changes to existing technologies in order to create new technologies (Albaladejo \& Romijn, 2000) related to processes, products, and organization. Innovation capacity is affected by internal and external sources. Among internal resources are occupation and education of the founder or manager, skills and expertise of employees, and technological achievements in the company. Among external sources of innovation capacity are frequency of cooperation with other companies and individuals, advantages arising from location of cooperation and the type and extent of received support.

\section{Results of Innovation Activities}

In general, results of innovation activities are different products, services, and/or processes. In the literature, the analysis and understanding of this phenomenon are quite extensive. The literature (Stieglitz \& Heine, 2007; Hill \& Rothaermel, 2003; Van de Ven, 1986) distinguishes a wide range of innovation types within a company (product/process, radical/incremental, technological/managerial, market pull/technology push, or competence-enhancing/competence-destroying). The adoption of an innovation includes "generation, development, and implementation of new ideas or behaviours" (Damanpour, 1991).

Innovations are mostly developed in a structured process. Veugelers and Cassiman (1999) define the innovation process as a range of activities that have varying degrees of risk. However, even the definition of innovation and its types varies. The three most frequently cited typologies differentiate between administrative and technical innovation, product and process innovation, and radical and incremental innovation (Gopalakrishnan \& Damanpour, 1997). Technical innovations include products, processes, and technologies used to produce products or services and are related to the basic activities in the company (Gopalakrishnan \& Bierly, 2001), whereas administrative innovations are related to organizational structures and processes (Damanpour, 1996). Product innovations are products or services implemented for the benefit of customers, while process innovations are different tools, equipment, and expertise in manufacturing technology involved in the transformation of inputs into outputs (Ettlie \& Reza, 1992). Each of these types of innovation can be developed by the company itself or in cooperation with other companies or institutions. Detailed definitions of concepts used in this paper are described in a later section, along with the methodology.

\section{The Importance of Supporting Innovation at the National Level}

The government at the national level can decide whether to get involved in innovation activities or not, with each approach impacting companies. In general, a government may want to participate in the innovation process for several reasons (Afuah, 2003, p. 307), including the nature of the knowledge underpinning innovations, the uncertainty bounded with the innovation process, the need for complementary assets, the nature of particular technologies, and the politics involved in many innovation-related regulations. 


\section{Methodology}

This paper relies on the methodology and database of the Community Innovation Survey 2008 (CIS) (CIS 2008 database). Although the database has been criticized in existing literature, it provides comprehensive insights into companies' innovation. The database's information allows for a comparative assessment of the innovation performance of EU member states and accession candidates. In 2008, the methodology was revised and combined into three categories - enablers, firm activities, and outputs - displaying seven dimensions and 29 indicators (Hollanders \& van Cruysen, 2008). The current paper used only selected data, which were divided into four groups of indicators:

- Enablers of innovation activities (acquisition of machinery, equipment, and software; acquisition of external knowledge; training for innovative activities);

- Characteristics of performing innovation activities (in-house R\&D, external R\&D, market introduction of innovations, others);

- Cooperation in innovation activities (with other companies within a company's group; suppliers of equipment, materials, components, or software; clients or customers; competitors or other companies in the same sector; consultants, commercial labs, or private R\&D institutions; government or public research institutions) and valuable of these types of cooperation;

- Financial support for innovation activities (acquired from local or regional authorities, central governments, or the European Union);

- Results of innovation activities (companies introducing new or improved technological innovation-products or processes; companies introducing new or improved non-technological innovation-organisational or market).

The population of the CIS 2008 is determined by the size of the company and its principal activity. All companies with 10 or more employees in any of the specified sectors were included in the statistical population. The reference period of the CIS 2008 was the year 2008. Definitions and descriptions of main indicators used in our research were summarized from different methodologies, including the Oslo Manual (OECD, 2005) and national statistical offices in Croatia (Croatian Bureau of Statistics, 2010) and Slovenia (Mervic, 2010). Companies in the survey were grouped according to their innovation activities. Active innovation companies were those that have introduced product innovation or process innovation, those that have not yet completed or abandoned the innovation activity during the observation period, and/or those that introduced organisational and/or marketing innovation. Meanwhile, non-innovative companies referred to those that, during the observation period (2006-2008), have not introduced any innovation and have had no innovation activity. Companies that introduced innovation/innovations within each type of innovation during the observed period were defined as innovators (product innovators, process innovators, organisational innovators, marketing innovators).

Innovation includes new goods, services, and processes or significantly improved goods, services, and processes. Innovation is implemented when it is introduced on the market (product innovation) or used in the process (process innovation). An innovative company has, during the observation period, introduced new or significantly improved products or processes. Innovation is based on the results of new technological development, new combinations of existing technologies, or the use of other knowledge used by the company. Innovation should be new to the company or the market. It is not relevant whether the innovation was 
developed by the company or not.

The methodology used included technological and non-technological types of innovations. Technological innovations include:

- Product (good or service) innovation (the market introduction of a new good or service or a significantly improved good or service with respect to its capabilities, such as improved software, user-friendliness, components, or sub-systems);

- Process innovation (the implementation of a new or significantly improved production process, distribution method, or support activity for goods or services).

Non-technological innovations include:

- Organisational innovation (the implementation of new business practices for organising procedures, new methods of organising work responsibilities and decision making, and new methods of organising external relations with other companies or public institutions);

- Marketing innovation (implementation of significant changes to the aesthetic design or packaging of a good or a service, which also covers new media or techniques for product promotion, new methods for product placement or sales channels, and new methods of pricing goods or services).

Innovation activities include the acquisition of machinery, equipment, software, and licenses as well as engineering and development work, training, marketing, and R\&D when they are specifically undertaken to develop and/or implement a product or process innovation. The following types of innovation activities were observed: research and development, procedures and technical preparations to implement new or significantly improved products and processes that are not covered elsewhere, and activities for the market introduction of new or significantly improved goods and services, including market research and launch advertising. In addition, three groups of acquisitions of results of knowledge were examined, namely: (1) acquisition of advanced machinery, equipment, and computer software to produce new or significantly improved products and processes; (2) purchase or licensing of patents and non-patented inventions, know-how, and other types of knowledge from other companies or organisations; and (3) training of personnel specifically for the development and/or introduction of new or significantly improved products and processes.

\section{Results of Empirical Analysis}

The survey on innovation engaged 7,374 companies from Croatia and 4,594 companies from Slovenia. As Table 1 indicates, $44.2 \%$ of companies in Croatia and $50.3 \%$ of companies in Slovenia performed innovation activities.

Table 1

Share of Innovative and Non-innovative Companies in Croatia and Slovenia

\begin{tabular}{lll}
\hline Country & Non-innovative companies & Companies with innovation activity \\
\hline Croatia & $55.8 \%$ & $44.2 \%$ \\
Slovenia & $49.7 \%$ & $50.3 \%$ \\
\hline
\end{tabular}

Note. Source: CIS 2008 database (2010); Based on the author's own calculations.

Compared with EU27, where $51.6 \%$ of companies (408,964 of 793,049 companies) were involved in innovation activities, both analysed countries perform below the average. Thus, as a starting point, the share of companies with innovation activities should be increased in the future. 


\section{Engagement in Innovation Activities}

Table 2 provides an overview of innovation activities performed internally or externally by a given company. In-house R\&D activities are defined as creative work undertaken within the company to increase the knowledge for developing new and improved products and processes (CIS 2008 methodology, 2010).

Table 2

Engagement in Innovation Activities by Type of Activities

\begin{tabular}{lllll}
\hline Country & In-house R\&D & External R\&D & Activities for market introduction of innovations & Other activities \\
\hline Croatia & $35.2 \%$ & $25.3 \%$ & $34.2 \%$ & $32.8 \%$ \\
Slovenia & $50.6 \%$ & $24.5 \%$ & $31.0 \%$ & $27.4 \%$ \\
\hline
\end{tabular}

Note. Source: CIS 2008 database (2010); Based on author's own calculations.

The results indicate that more than a half of Slovenian companies with innovation activities perform their own R\&D while only $35 \%$ of Croatian companies do so. The external R\&D is defined in the same way as in-house $\mathrm{R} \& \mathrm{D}$ with the difference that it is performed by other companies or organisations and purchased by a given company (CIS 2008 methodology, 2010). The purchasing of external R\&D activities shows a much smaller difference between Slovenian and Croatian companies; in both countries, approximately one quarter of companies acquire R\&D externally on the market. The third element represents activities for the market introduction of new or improved products and services, including market research (CIS 2008 methodology, 2010). The last element comprises other activities for implementing improved products and processes, such as feasibility studies and testing (CIS 2008 methodology, 2010). In both countries, about one third of companies provide these two analysed elements.

\section{Enablers of Innovation Activities}

Table 3 depicts the enablers of innovation activities in companies with innovation activities. As enablers of innovation, the activities included all of a company's actions and acquisitions to acquire different equipment and knowledge in trainings from its environment. Three indicators were defined: (1) acquisition of machinery, equipment, and software; (2) acquisition of external knowledge; and (3) training for innovative activities.

Table 3

Enablers of Innovation Activities

\begin{tabular}{llll}
\hline Country & $\begin{array}{l}\text { Acquisition of machinery, } \\
\text { equipment and software }\end{array}$ & Acquisition of external knowledge & Training for innovation activities \\
\hline Croatia & $67.7 \%$ & $25.0 \%$ & $48.3 \%$ \\
Slovenia & $53.5 \%$ & $24.4 \%$ & $33.5 \%$ \\
\hline
\end{tabular}

Note. Source: CIS 2008 database (2010); Based on author's own calculations.

In both countries, the majority of companies acquire machinery, equipment, and software, although in higher share do so in Croatia (67.7\%) than in Slovenia (53.5\%). However, only a quarter of companies in both countries acquire external knowledge, which is one of the important factors enabling internal innovation. Although training is used in almost half of Croatian companies, only one third of companies in Slovenia use it. All measured indicators occurred at a higher level in Croatian companies than in Slovenian ones. In general, this indicates that activities undertaken by companies to enable internal innovation activity are not used frequently enough. Acquiring external knowledge or its results is important for companies to broaden their knowledges and improve their absorptive capacities, which enables the application of acquired knowledge. 


\section{Cooperation in Performing Innovation Activities}

Cooperation in innovation activities may occur in different forms, and companies may cooperate with several different types of companies and institutions. In Croatia, $30 \%$ of the companies with innovation activities cooperated with other actors; $33 \%$ of companies in Slovenia did so. Figure 1 summarizes the results of cooperation with seven groups of actors.

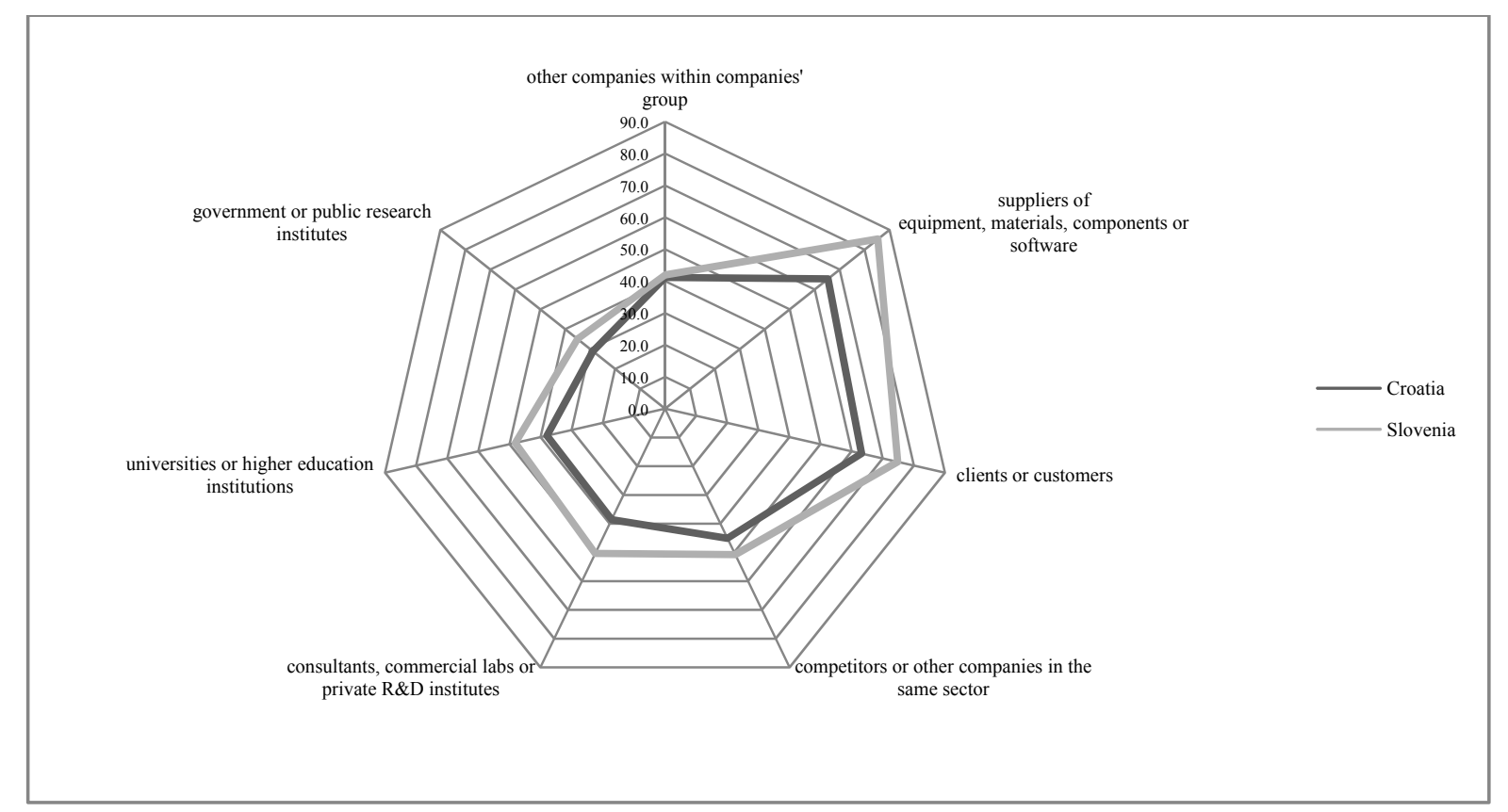

Figure 1. Types of innovation cooperation. Source: CIS 2008 database (2010); Based on author's own calculations.

Most companies cooperate with suppliers of equipment, materials, components, or software as well as with clients and customers. Both groups of co-operators are within the company's principal value-chain. However, all other types of cooperation occur at a much lower level. The least cooperating companies cooperate with government or public research institutes and universities. These results coincide with a low level of technology transfer from universities to the business sector. They further indicate that the triple helix is still not a practice in any of the compared countries.

The most valuable type of innovation cooperation is shown in Figure 2. In accordance with previous findings, cooperation with government or public research institutes as well as with universities was the least valuable, while cooperation with suppliers of equipment, materials, components, or software was the most valuable one.

\section{Financial Support for Innovation Activities}

The majority of national or local governments provide some form of financial support for companies' innovation activities. Table 4 provides results from the analysis of financial support provided by three groups of actors - namely, local or regional authorities, central or national government, and the European Union. Croatian companies received more support from local, regional, or central government than Slovenian ones. Slovenian companies received significantly more support from the European Union than Croatian companies due to the fact that Croatia is still an EU candidate country and is not entitled to as many financial support schemes or incentives as Slovenia (an EU country). Therefore, this indicator will be appropriate for comparison 
only after Croatia joins the European Union.

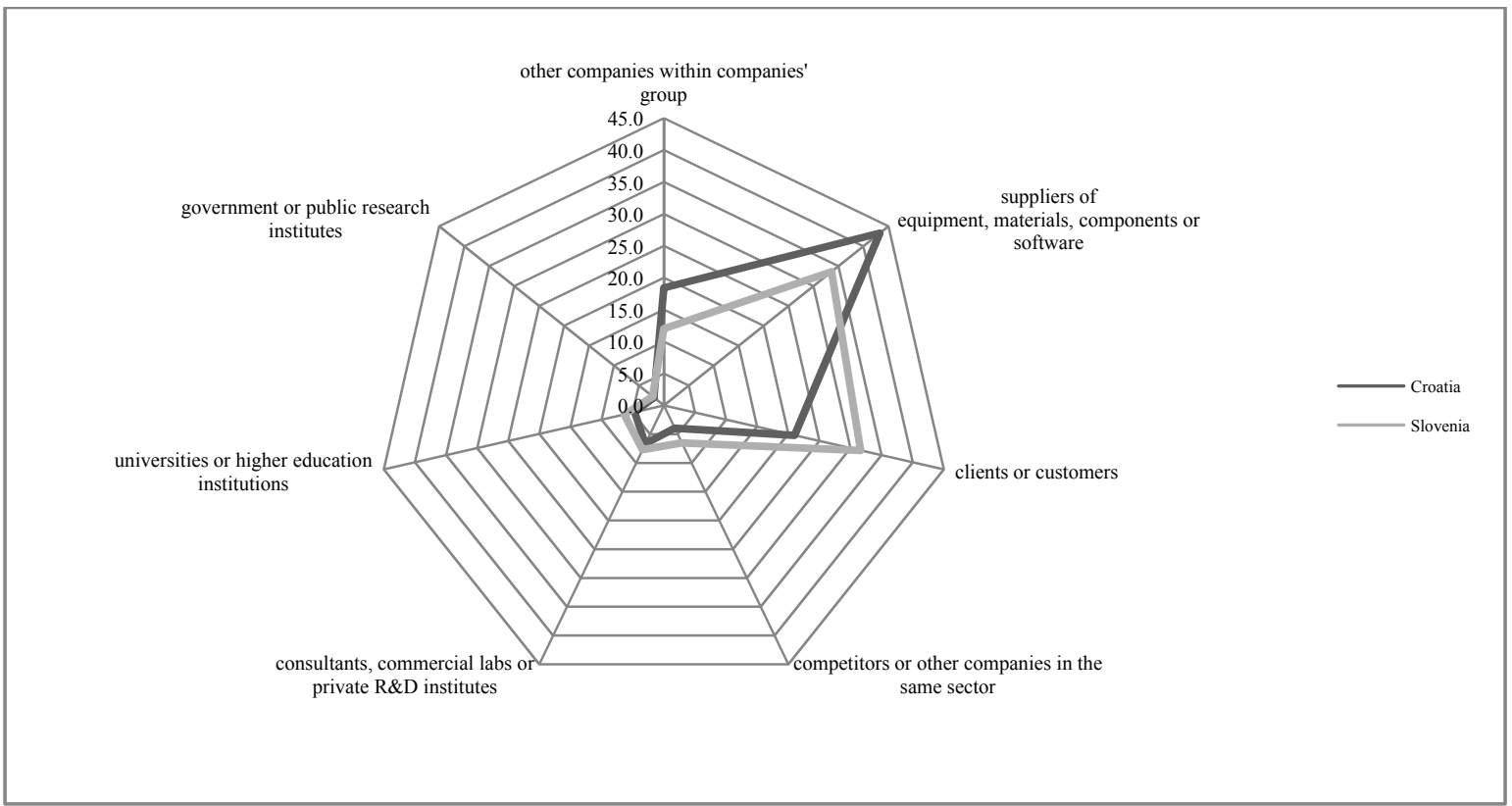

Figure 2. The most valuable types of innovation cooperation. Source: CIS 2008 database (2010); Based on author's own calculations.

Table 4

Companies Receiving Financial Support for Innovation Activities

\begin{tabular}{lllc}
\hline Country & $\begin{array}{l}\text { Acquisition of machinery, } \\
\text { equipment and software }\end{array}$ & Acquisition of external knowledge & Training for innovation activities \\
\hline Croatia & $20.0 \%$ & $87.6 \%$ & $5.9 \%$ \\
Slovenia & $8.7 \%$ & $72.2 \%$ & $49.5 \%$ \\
\hline
\end{tabular}

Note. Source: CIS 2008 database (2010); Based on author's own calculations.

Both compared countries face many challenges regarding innovation policy and innovation support. Croatia's main innovation policy challenges are providing access to capital for innovation projects, stimulating $\mathrm{R} \& \mathrm{D}$ expenditures, and facilitating intellectual property protection (European Commission, 2009a). Slovenia's main policy challenges are stimulating $R \& D$ investments, ensuring the transparency of innovation support institutions, and increasing innovation activities in particular groups of companies, namely, small companies (European Commission, 2009b). Innovation challenges facing both countries are comparable to supporting R\&D, because too many companies rely on suppliers' innovations and improvements while the companies lack internal R\&D. R\&D comprises creative and systematic work intended to increase knowledge of human beings, culture, and society. The use of this knowledge for the development of new applications relates to three activities: basic research, applied research, and experimental development. The primary aim is not to develop new or improved products or processes, but rather new knowledge that is still not sellable. This is one of important reasons why companies do not perform $\mathrm{R} \& \mathrm{D}$, as it represents only sunk costs that concentrate primarily on innovation activities.

\section{Results of Innovation Activities}

Innovation activities give rise to innovations. Research groups innovations into product innovations new 
to the company or new to the market, organisational innovations, and market innovations. Table 5 presents shares of companies with different types of innovation in Croatia and Slovenia.

Table 5

Companies With Different Types of Innovation

\begin{tabular}{lllll}
\hline Country & $\begin{array}{l}\text { Companies with } \\
\text { organisational innovation }\end{array}$ & $\begin{array}{l}\text { Companies with market } \\
\text { innovation }\end{array}$ & $\begin{array}{l}\text { Companies with product } \\
\text { innovation new to the } \\
\text { market }\end{array}$ & $\begin{array}{l}\text { Companies with product } \\
\text { innovation new to the } \\
\text { company }\end{array}$ \\
\hline Croatia & $43.5 \%$ & $42.5 \%$ & $28.1 \%$ & $39.2 \%$ \\
Slovenia & $39.2 \%$ & $39.1 \%$ & $35.0 \%$ & $41.5 \%$ \\
\hline
\end{tabular}

Note. Source: CIS 2008 database (2010); Based on author's own calculations.

The results show that among companies there are several differences by a type of innovation. Most Slovenian companies provided product innovation new to the company $(41.5 \%)$ and the least product innovation new to the market (35\%). In Croatia, the majority of companies provided organisational innovation $(43.5 \%)$ and the least product innovation new to the market (28.1\%). However, Slovenian companies provided more product innovation than Croatian companies while Croatian companies provided more organisational and market innovations than Slovenian ones. The most important and relevant innovations for customers are product innovations new to the market, which also have the highest level of risk; therefore, it is expected to be at the lowest level in both countries.

\section{Conclusions}

This paper sought to contribute to the understanding of innovation in two countries, Croatia and Slovenia. Empirical findings indicated that innovation performance is still not at a level that would provide a sustainable competitive advantage. The five determinants investigated were enablers of innovation activities, characteristics of performing innovation activities, cooperation of performing innovation activities, financial support for innovation activities, and results of innovation activities. Based on the analysis of these five areas, the most important issues for both countries are as follows:

- Only a third of Croatian companies provide internal R\&D while a half of Slovenia companies do;

- The acquisition of various types of knowledge is better in Croatian companies than in Slovenian companies, particularly in terms of training and equipment acquisition;

- Innovation cooperation with different actors in a company's environment is higher in Slovenian companies than in Croatian companies; nevertheless, only approximately one third of them cooperate. Companies in both countries mostly cooperate with suppliers, clients, and customers. The level of cooperation with universities and government is very low;

- Croatian companies exploit financial support from the government more successfully than Slovenian companies;

- Comparing the innovations as results of innovation activities, Croatian companies provide more organisational and market innovations than Slovenian ones. On the other hand, Slovenian companies provide more product innovation (new to the company and to the market).

Such results underscore some important implications for innovation policy. The basic challenge is how to engage more companies in performing innovation activities and how to motivate them to engage in more internal innovation activities and R\&D. As the level of cooperation is relatively low, policymakers should find 
mechanisms that would enable and support cooperation and at the same time prevent companies from possible opportunistic behaviour (Rebernik \& Bradač, 2006). Currently, only one third of companies cooperate in performing innovation activities, mostly with suppliers and customers. To acquire new knowledge, companies should cooperate with universities and research institutions more - not only because they have a lot of knowledge, but also because in the two countries compared this knowledge is created by public funding and should be more efficiently exploited. In both Croatia and Slovenia, technology transfer is at a very low level, and appropriate transfer routines should be created. This cooperation between the business and "science" sector represents the next challenge for policymakers in Croatia and Slovenia seeking to set effective measures to foster such creative cooperation.

\section{References}

Afuah, A. (2003). Innovation management. New York: Oxford University Press.

Albaladejo, M., \& Romijn, H. (2000). Determinants of innovation capability in small UK firms: An empirical analysis. Working Paper series 00.13, Eindhoven Centre for Innovation Studies, The Netherlands.

Andandre, C., \& Furtado, J. (2006). Innovation and manufacturing in assembly industries: A comparative analysis of outsourcing approaches on automobiles and electronics. Proceedings from GERPISA 14th International Colloquium, Paris.

Arora, A., \& Gambardella, A. (1990). Complementarity and external linkages: The strategies of the large firms in biotechnology. Journal of Industrial Economics, 38, 361-379.

Cassiman, B., \& Veugelers, R. (2006). In search of complementarity in innovation strategy: Internal R\&D and external knowledge acquisition. Management Science, 52(1), 68-82.

Chesbrough, H. W. (2003). The era of open innovation. MIT Sloan Management Review, 44(3), 35-41.

CIS 2008 database. (2010). Community innovation survey. Retrieved July 12, 2002, from http://epp.eurostat.ec.europa.eu/portal/page/portal/science_technology_innovation/data/database

CIS 2008 methodology. (2010). Statistical presentation. Retrieved July 12, 2011, from http://epp.eurostat.ec.europa.eu/cache/ITY_SDDS/en/inn_esms.htm

Croatian Bureau of Statistics. (2010). Innovation activities in Croatian enterprises. Retrieved July 12, 2011, from http://www.dzs.hr/default_e.htm

Damanpour, F. (1991). Organizational innovation: A meta-analysis of effects of determinants and moderators. Academy of Management Journal, 34(3), 555-590.

Damanpour, F. (1996). Organizational complexity and innovation: Developing and testing multiple contingency models. Management Science, 42, 693-716.

Ettlie, J., \& Reza, E. (1992). Organizational integration and process innovation. Academy of Management Journal, 34(4), 795-827.

European Commission. (2004). Innovation management and the knowledge-driven economy. Brussels: Directorate-general for Enterprise.

European Commission. (2009a). INNO-policy trend chart-Innovation policy progress report: Croatia. Brussels: Enterprise Directorate General.

European Commission. (2009b). INNO-policy trend chart-Innovation policy progress report: Slovenia. Brussels: Enterprise Directorate General.

European Commission. (2010). European innovation scoreboard 2009: Comparative analysis of innovation performance. Brussels: European Union.

Freeman, C., \& Soete, L. (1997). The economics of industrial innovation (3rd ed.). GB: MIT Press.

Gopalakrishnan, S., \& Bierly, P. (2001). Analyzing innovation adoption using a knowledge-based approach. Journal of Engineering and Technology Management, 18, 107-130.

Gopalakrishnan, S., \& Damanpour, F. (1997). A review of innovation research in economics, sociology and technology management. The International Journal of Management Science, 25(1), 15-28.

Granstrand, O., Bohlin, E., Oskarsson, C., \& Sjoberg, N. (1992). External technology acquisition in large multitechnology corporations. R\&D Management, 22, 111-133. 
Hill, C., \& Rothaermel, F. (2003). The performance of incumbent firms in the face of radical technological innovation. Academy of Management Review, 28(2), 257-274.

Hollanders, H., \& van Cruysen, A. (2008). Rethinking the European innovation scoreboard: A new methodology for 2008-2010 The Netherlands: UNU-MERIT.

Mervic, H. (2010). Innovation activity in manufacturing and selected services: Methodological explanations. Retrieved July 12 , 2011, from http://www.stat.si/doc/metod_pojasnila/23-059-ME.htm

OECD. (2005). Oslo manual, guidelines for collecting and interpreting innovation data. Paris: OECD and EUROSTAT.

Rebernik, M., \& Bradač, B. (2006). Cooperation and opportunistic behaviour in transformational outsourcing. Kybernetes, 35(7/8), 1005-1013.

Rigby, D., \& Zook, C. (2002). Open-market innovation. Harvard Business Review, 80(10), 80-89.

Stieglitz, N., \& Heine, K. (2007). Innovations and the role of complementarities in a strategic theory of the firm. Strategic Management Journal, 28(1), 1-15.

Van de Ven, A. (1986). Central problems in the management of innovation. Management Science, 32(5), 590-607.

Veugelers, R., \& Cassiman, B. (1999). Make and buy in innovation strategies: Evidence from Belgian manufacturing firms. Research Policy, 28, 63-80. 